\title{
APPLICATION OF LANDSCAPE METRICS AND GIS TECHNIQUES FOR ASSESSMENT OF LAND USE AND LAND COVER CHANGES IN THE SUCEAVA RIVER BASIN, ROMANIA
}

DOI: http://dx.doi.org/10.18509/GBP.2019.70

UDC: 528.93:556.5(498)

\author{
Horodnic Vasilică-Dănuț ${ }^{1}$ \\ Bistricean Petruț-Ionel ${ }^{2,1}$ \\ Mihăilă Dumitru' \\ Efros Vasile ${ }^{1}$ \\ 1 "Ștefan cel Mare" University of Suceava, Faculty of History and Geography, Department of \\ Geography, Suceava, Romania \\ ${ }^{2}$ National Meteorological Administration, Regional \\ Meteorological Centre of Moldova, Iași, Romania
}

\begin{abstract}
Land use and land cover integrate various aspects of natural and socio-economic features of the environment. Land use and cover change reflect the interaction among the environmental features and processes and human activities. After the collapse of the socialism regime in 1989, Romania has undergone significant changes at the level of socio-economic and institutional profile, which determined land use scientists to consider our country to be an experimental territory for land use research. Considering land use and cover plots as pieces of landscape configuration, landscape metrics can provide valuable information about structural changes occurred in land use and cover spatial pattern. Using the Suceava River Basin from Romania as a case study, a hybrid geographical approach applying landscape metrics and GIS techniques was applied to analyse the spatial and temporal dynamics of land use and cover pattern changes between 1990 and 2012. In order to assess the land use and cover changes, we used a series of relevant landscape metrics at class and landscape level in order to quantify the landscape composition and its spatial configuration. The analysis was carried out using CORINE Land Cover datasets from 1990, 2000, 2006 and 2012 by means of geographic information systems to present the spatial distribution of the data, while FRAGSTATS software was employed to process landscape metrics in order to generate statistics about landscape structure. The results highlight an increase in the number of patches and edge density, while the mean patch size decreased during the span of 22 years. Consequently, the landscape structure of Suceava River Basin became more fragmented and heterogeneous. We hope that the present approach will underline the importance of using landscape metrics in monitoring land use and cover changes over time by decision makers as a powerful basis of sustainable land use planning at the entire basin level.
\end{abstract}

Keywords: landscape metrics, land cover changes, fragmentation, patch, patterns

\section{INTRODUCTION}

Landscape metrics are important for measuring, analyzing, and interpreting spatial patterns of landscapes. During the last several decades, a number of various landscape metrics were developed to describe and quantify the composition and arrangement of landscape mosaics. 
Landscapes are the result of a continuous land reorganization to adapt their use and spatial structure to the changes of economic and social demand throughout history [1]. Quantitative analysis of the structure of a landscape, as well as how it has changed over time, could be performed through the use of landscape metrics [2]. Scientists who study landscape ecology have used different terms to talk about the elementary elements that define a landscape [3]. In the scientific literature, the term that occurs most often is patches. In fact, when we talk about the landscape metrics, the landscape is often defined as a composition of a mosaic of patches [4] and, by quantifying their specific spatial characteristics, it is possible to describe the landscape metrics and therefore the landscape structure. The main application fields are, for example, biodiversity and habitat quality analysis, estimation of water quality, urban landscape pattern, landscape aesthetics, management, planning, and monitoring [5].

Landscape metrics address the spatial composition and configuration of landscapes and are important tools for understanding, assessing, and monitoring changes in landscape pattern, which affect underlying ecological processes. Landscape metrics are widely used due to easy calculation with easily obtained land cover data, from maps and remotely sensed images.

There are several software packages available for calculating a variety of landscape metrics, such as FRAGSTATS [6], PolyFrag [7], IAN [8], APACK [9], Conefor [10], DIY [11], Patch Analyst in ArcGIS [12], Pattern and texture modules in IDRISI [13] and LecoS plug-in of QGIS. For example, FRAGSTATS provided around 43 landscape metrics at class level [14]. One of these software packages works with data in a raster format like FRAGSTATS or IAN and APACK, while Patch Analyst extension for ArcGis provides both vector and raster-based patch analysis while Vector-based Landscape Analysis Tool (V-LATE) extension for ArcGis, PolyFrag and DIY programs work with data in a vector format. The LandMetrics-3D, a user-friendly freeware tool allows for the inclusion of altitude and relief information into a variety of landscape metrics [15]. The recent researches also provide the potential of Zonal Metrics - an ArcGis Pyton toolbox for zonal landscape structure analysis and $\mathrm{R}$ package for calculating landscape metrics for categorical landscape patterns. Finally, the Interactive Metrics Tool (IMT) - a vector-based landscape structure analysis designed for didactical purposes is an interesting software comprises customized ESRI ArcView projects along with pre-pared MS Excel spreadsheets and a MS PowerPoint sequence for interactively control [16].

In Romania, most of the studies that took into account the application of landscape metrics to landscape change research have approached different territorial structures on several spatial levels (villages, cities, metropolitan areas, protected areas or major landform units). Moreover, the main application of landscape metrics was to quantify the changes in spatial pattern of landscape or the tendencies of landscape processes as a consequence of the increase in human pressure on the natural environment. In line with this statement, the main research directions can be summarized as they follow: the analysis of landscape dynamics [17], [18], [19]; the investigation of changes in landscape structure and functionality caused by infrastructure transportation projects [20] or by tourism activities development [21], [22]; the quantification of landscape fragmentation and pattern in different protected areas in conjunction with land cover changes [23], [24], [25], [26], [27].

The main goal of our reasearch is to quantify the spatio-temporal patterns and trends of land cover and land use changes in Suceava River Basin by the application of a diachronic 
analysis of freely available CORINE Land Cover datasets of time steps 1990, 2000, 2006 and 2012, landscape metrics and GIS techniques.

In order to identify and understand the spatial and temporal pattern of changes in natural and cultural landscapes of Suceava River Basin, our detailed objectives are following:

1. determination of the quantitative changes in land use/land cover classes area in 3 time intervals, covering periods 6-10 years: 1990-2000, 2000-2006, 2006-2012;

2. assessment in which time section the change of land use/land cover extent in the analyzed area was more intensive by determining the rate of change and the landscape change index (LCI);

3. quantification of the landscape composition, configuration, shape and diversity by the application of several landscape metrics;

4. identification of the main driving forces that caused changes in landscape pattern in the study area.

\section{MATERIALS AND METHODS}

\section{Study area}

The Suceava hydrographic basin is located in the northeastern part of Romania (Suceava County) and in the southwestern part of Ukraine (Chernivtsi Oblast), having an elongated shape and is disposed approximately from NW to SE direction.

The Suceava drainage basin borders in north and east by Siret drainage basin, in southeast and south by Șomuzul Mic, Șomuzul Mare and Moldova drainage basins, respectively, in southwest by Bistriţa drainage basin, while in west and northwest is bordered by Prut drainage basin (Figure 1).

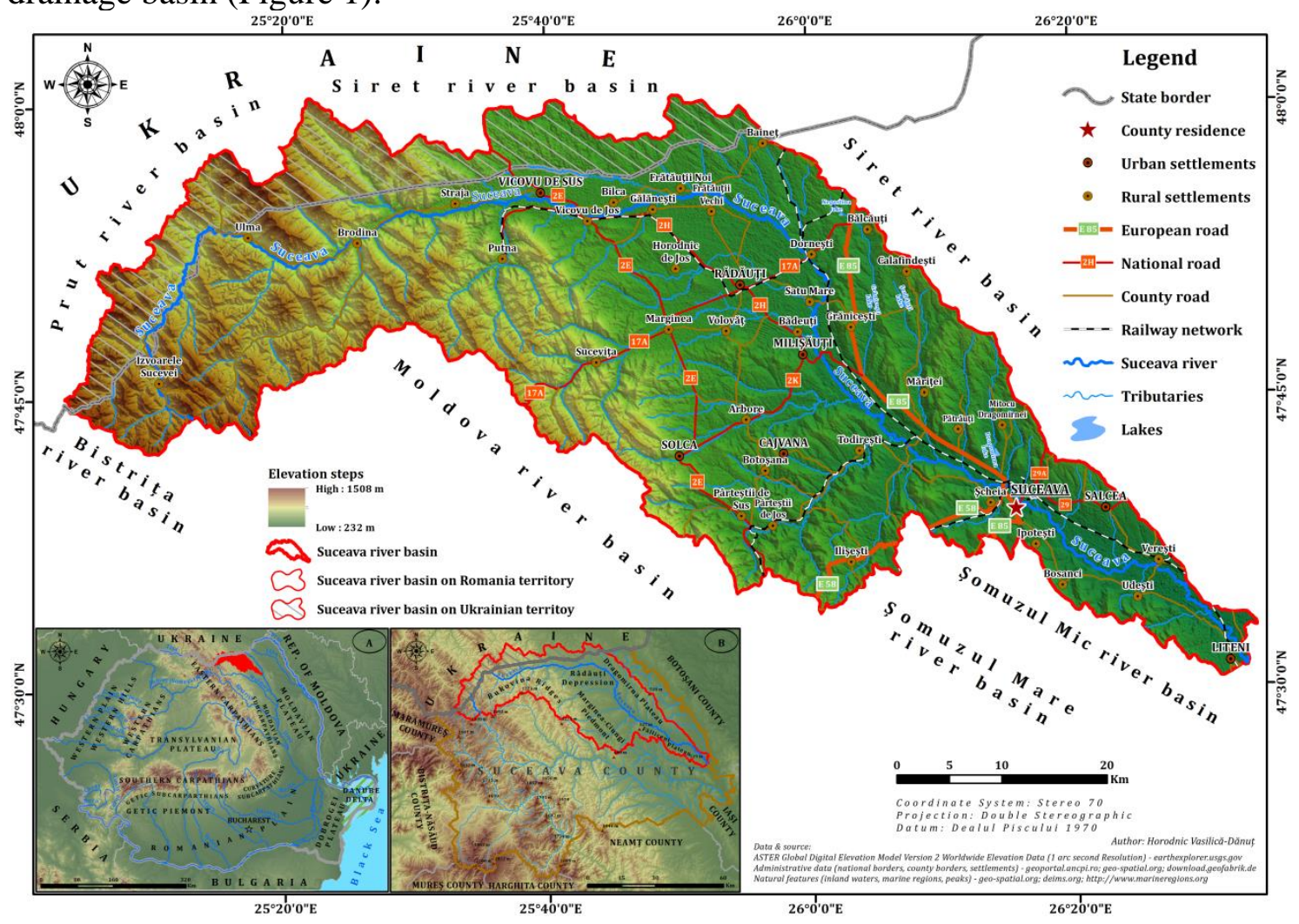

Figure 1. Geographical position of the Suceava River Basin within Romania's main landform units (A) and Romania-Ukraine international border (B) 
Suceava River, a right tributary of the Siret River, has a drainage basin that extends in Romania within the following geographical coordinates: $47^{\circ} 31^{\prime}$ and $47^{\circ} 59^{\prime}$ North latitude, and $25^{\circ} 05^{\prime}$ and $26^{\circ} 33^{\prime}$ East longitude. With a length of $172.3 \mathrm{~km}$, it has its source on the northeastern slope of the Bobeica Peak and Hrobi Peak from Obcina Mestecăniş, and it flows into the Siret River downstream the Liteni Town. The altitude ranges from $1508 \mathrm{~m}$ registered at basin's springs to $232 \mathrm{~m}$ reached at its mouth, with an absolute difference of $1276 \mathrm{~m}$ [28]. Between Șipot and Ulma, on a distance of $21 \mathrm{~km}$, it forms the border with Ukraine.

The Suceava River Basin covers about $2632 \mathrm{~km}^{2}$, with $86.66 \%$ of the area in Romania and $13.34 \%$ in Ukraine $\left(351 \mathrm{~km}^{2}\right)$. The area under study is located on Romanian territory of the basin that means $2281 \mathrm{~km}^{2}$, framed entirely in Suceava County, representing about $26.67 \%$ of its surface and about $0.96 \%$ of the surface of Romania.

In the tectonic structure of the Suceava River Basin there are two major geostructural components: the orogenic area and the platform area, between which a contact area, which we have called a transition area.

From a geomorphological point of view, the drainage basin of the Suceava River overlaps three sectors with distinct physical-geographical features, from west to east. The mountain sector where the Suceava River drains the eastern edge of the northern group of the Eastern Carpathians (Bukovina Ridges - Obcina Mestecănișului, Obcina Feredeului and Obcina Mare). The transition sector to the plateau region comprises a piedmont area (Marginea-Ciungi Piedmont) and a succession of different size depressions (Solca, Cacica). The eastern area belongs to Suceava Plateau - a subunit attached to the Moldavian Plateau, which includes western part of the Dragormirna Plateau, Rădăuți Depression, Horodnic Depression, Iaslovăț Depression, the northern part of the Fălticeni Plateau and Suceava River valley [29].

The Suceava River Basin is located in the moderate temperate climate of transition influences. The mean annual temperature ranges from $3.63^{\circ} \mathrm{C}$ (Izvoarele Sucevei) to $7.5^{\circ} \mathrm{C}$ (Rădăuți), $7.9^{\circ} \mathrm{C}$ (Suceava) and $9.02^{\circ} \mathrm{C}$ (Verești). The annual rainfall recorded in the watershed for the years between 1961 and 2013 ranges from $982.46 \mathrm{~mm}$ (Izvoarele Sucevei) to $630.7 \mathrm{~mm}$ (Rădăuți), $629.21 \mathrm{~mm}$ (Suceava) and $617.35 \mathrm{~mm}$ at Verești [30]. The basic feature of the wind regime in the area under investigation is the predominance of the winds from northwest and southeast directions. The average annual wind speed at Rădăuţi meteorological station is $3.3 \mathrm{~m} / \mathrm{s}$, while the atmospheric calm has a frequency of $32 \%$. The other side, at Suceava meteorological station, the average annual wind speed is $3.8 \mathrm{~m} / \mathrm{s}$, while the atmospheric calm has a frequency of $34.8 \%$ [31].

In terms of vegetation spreading in the Suceava River Basin there are four layers of vegetation: coniferous layer composed of spruce and fir tree (9\%), mixed forests layer composed of spruce, fir and beech $(77.6 \%)$, beech layer $(0.9 \%)$ and mixed hardwoods floor from the hilly areas composed of oak and beech species expanding to about $12.5 \%$ of the total study area [32].

The soils appearing in the basin belong to six soil classes, which vary from one sector to another as a surface, these being the classes of argiluvisols, cambisols, spodosols, molisols (cernisols), hydromorphic soils (hidrisols) and protosols [33].

The network of settlements in the studied area comprises 50 administrative-territorial units, of which 8 are towns and 42 are communes with the associated villages (a total of 143 settlements), resulting an average density of 15.93 localities $/ \mathrm{km}^{2}$. 


\section{Research Methodology}

A series of landscape metrics minimally redundant and easily interpretable were calculated using the Fragstats 4.2 free program [34], to assess the multi-temporal patterns of landscape structure changes [35]. The basis of the spatial metric calculation was land cover maps of different years realized by the application of diachronic analysis.

The complexity of the research of land use and land cover changes requires an integrated approach research that combines basic geographical principles, specific concepts and particular research methods and techniques of land system investigation. The methodological flowchart is based on several steps that are presented in Figure 2.

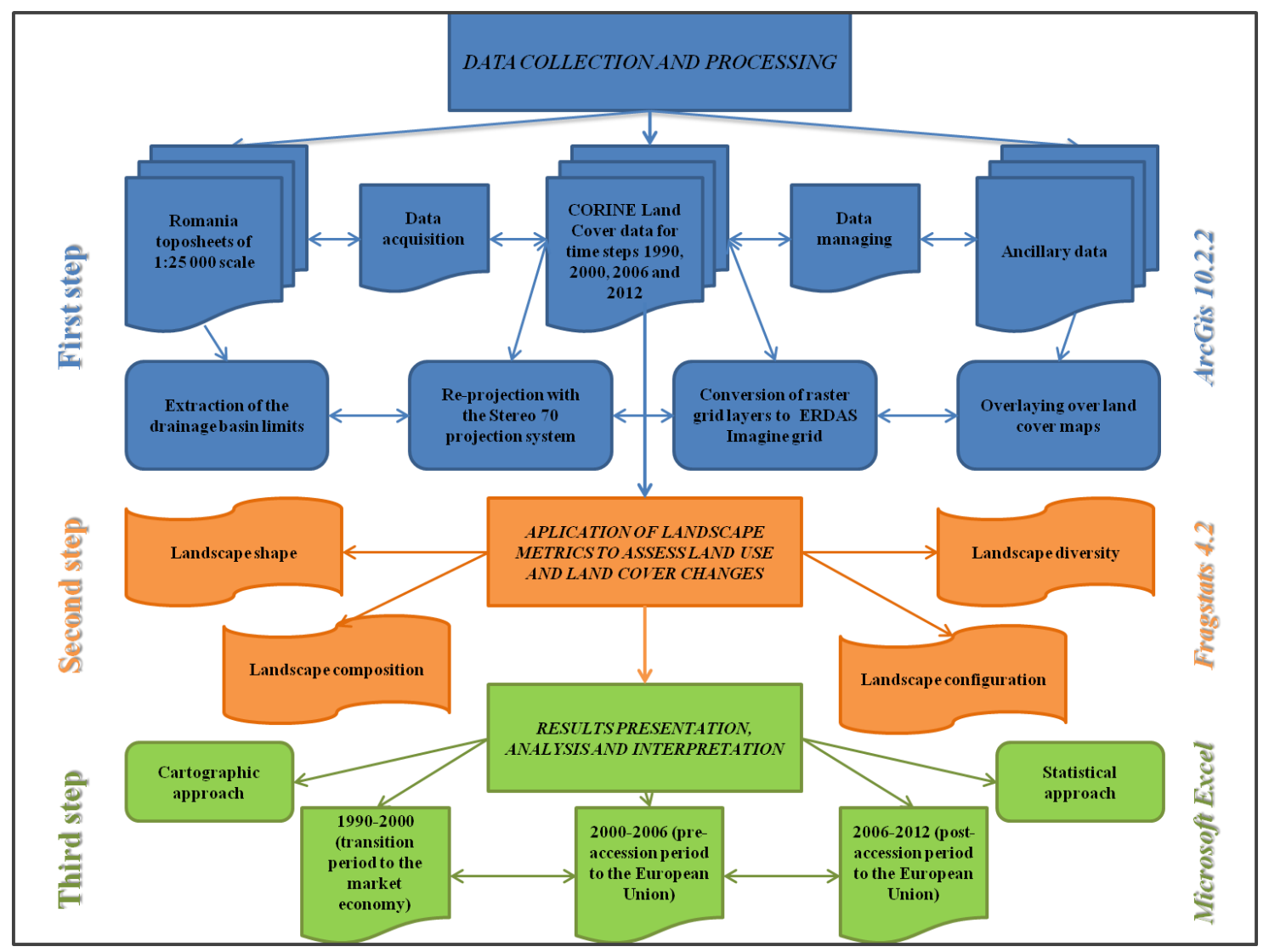

Figure 2. Flowchart of the methodological research steps

The first step includes data collection and GIS basic applications, such as, data aquisition, managing, basic analyzing and displaying of georeferenced data. The study of land use and land cover change inevitably involves characterization of landscape pattern using thematic maps classified mostly from remote sensing data. To highlight the land use and land cover changes changes in the study area, we used three categories of data. The first set of data is represented by Romania topographic map of 1:25000 scale on the basis of which we construct the Digital Elevation Model for the area under study and we extract the limits of Suceava drainage basin. The second category of data is represented by the datasets of the European Environmental Agency (EEA) in the context of the CORINE Land Cover (CLC) project for time steps 1990, 2000, 2006 and 2012. Thirdly, the ancillary data corresponding to the study area as vector shapefile format were also used and overlayed over land cover maps.

We used in our analysis the data regarding land use/cover in raster format with $100 \times 100 \mathrm{~m}$ resolution. We also reproject the initial data with Stereo 70 national coordinate system. 
Another basic applications include the conversion of raster grid layers as ERDAS imagine grid format for future processing analysis in FRAGSTATS software.

The second phase of analysis consist of quantification of land use/cover changes by application of landscape metrics processed in FRAGSTATS software. This stage of work take into account four main categories of landscape metrics in order to asses the composition, the configuration, the shape and the diversity of landscape pattern. We rule the model parameterized using an 8-neighbor rule in FRAGSTATS software for land use/cover classes, whereas in the case of proximity index we have chosen a radius defined by 200 meters.

Finally, the presentation, the analysis and the interpretatin of the results obtained represented the third phase of the research. In this way, we apply a cartographic approach in order to highlight the spatial and temporal pattern of land use and cover changes occured at the level of the study area. On the other hand, a statistical and graphical approach were employed for the presentattion of the data strings.Investigation of the changes in spatial context of landscape pattern helps us to decipher and to understand the diversity of interconnectedness of human-environmental processes. To explore the level of fragmentation and its spatial configuration, several landscape metrics was calculated for each land use and cover classes at the entire landscape level by means of FRAGSTATS software. A set of 15 landscape metrics used were chosen to describe landscape composition, its spatial configuration, the shape of patches and the diversity of the landscape (Table 1).

Table 1. List of landscape metrics used in the study

\begin{tabular}{|c|c|c|c|c|}
\hline Type & $\begin{array}{l}\text { Landscape metrics and } \\
\text { abbreviation }\end{array}$ & Description & Unit & Range \\
\hline \multirow{6}{*}{ 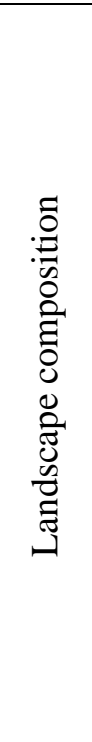 } & Class Area (CA) & $\begin{array}{l}\text { Sum of the areas }\left(\mathrm{m}^{2}\right) \text { of all patches of } \\
\text { the corresponding patch type. }\end{array}$ & Hectares & $\begin{array}{l}\mathrm{CA}>0 \\
\text { without } \\
\text { limit }\end{array}$ \\
\hline & $\begin{array}{c}\text { Percentage of } \\
\text { Landscape (PLAND) }\end{array}$ & $\begin{array}{l}\text { The relative contribution of each class } \\
\text { in the landscape. }\end{array}$ & Percent & $\begin{aligned} 0 & <\text { PLAND } \\
& \leq 100\end{aligned}$ \\
\hline & $\begin{array}{l}\text { Number of Patches } \\
\text { (NP) }\end{array}$ & $\begin{array}{l}\text { Equals the number of patches of the } \\
\text { corresponding patch type (class). }\end{array}$ & Unitless & $\begin{array}{c}\mathrm{NP} \geq 1 \\
\text { without } \\
\text { limit }\end{array}$ \\
\hline & $\begin{array}{l}\text { Mean Patch Size } \\
\text { (MPS) }\end{array}$ & $\begin{array}{l}\text { The average area of all patches in the } \\
\text { landscape }\end{array}$ & Hectares & \\
\hline & Edge Density (ED) & $\begin{array}{l}\text { The total length of all edge segments } \\
\text { per hectare for the class or landscape of } \\
\text { consideration }\end{array}$ & $\begin{array}{l}\text { Meters } \\
\text { per } \\
\text { hectare }\end{array}$ & $\begin{array}{l}\mathrm{ED} \geq 0 \\
\text { without } \\
\text { limit }\end{array}$ \\
\hline & $\begin{array}{l}\text { Largest Patch Index } \\
\text { (LPI) }\end{array}$ & $\begin{array}{c}\text { Quantifies the percentage of total } \\
\text { landscape area comprised by the largest } \\
\text { patch }\end{array}$ & Percent & $\begin{array}{c}0<\mathrm{LPI} \leq \\
100\end{array}$ \\
\hline \multirow{2}{*}{ 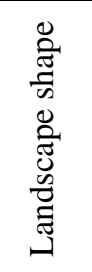 } & $\begin{array}{l}\text { Mean Shape Metric } \\
\text { (MN_SHAPE) }\end{array}$ & $\begin{array}{l}\text { Equals the sum, across all patches } \\
\text { divided by the total number of patches }\end{array}$ & Unitless & $\begin{array}{l}\text { SHAPE } \geq 1, \\
\text { without } \\
\text { limit }\end{array}$ \\
\hline & $\begin{array}{l}\text { Perimeter-Area Fractal } \\
\text { Dimension (PAFD) }\end{array}$ & $\begin{array}{c}\text { An index that reflects shape complexity } \\
\text { across a range of spatial scales (patch } \\
\text { sizes). }\end{array}$ & Unitless & $\begin{array}{c}1 \leq \\
\text { PAFRAC } \leq \\
2\end{array}$ \\
\hline
\end{tabular}




\begin{tabular}{|c|c|c|c|c|}
\hline \multirow{5}{*}{ 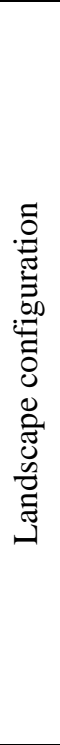 } & Contagion Index (CI) & $\begin{array}{l}\text { Measures both patch type interspersion } \\
\text { (i.e., the intermixing of units of } \\
\text { different patch types) as well as patch } \\
\text { dispersion (i.e., the spatial distribution } \\
\text { of a patch type) at the landscape level }\end{array}$ & Percent & $\begin{array}{c}0< \\
\text { CONTAG } \leq \\
100\end{array}$ \\
\hline & $\begin{array}{l}\text { Landscape shape index } \\
\text { (LSI) }\end{array}$ & $\begin{array}{l}\text { Measure the form of the patches and } \\
\text { indicates the compactness of landscape }\end{array}$ & Unitless & $\begin{array}{l}\mathrm{LSI} \geq 1 \\
\text { without } \\
\text { limit }\end{array}$ \\
\hline & $\begin{array}{c}\text { Mean Euclidean } \\
\text { Nearest Neighbor } \\
\text { Distance (ENN_MN) }\end{array}$ & $\begin{array}{c}\text { The distance to the nearest neighboring } \\
\text { patch of the same type, based on } \\
\text { shortest edge-to-edge distance }\end{array}$ & Meters & $\begin{array}{c}\text { ENN >0, } \\
\text { without } \\
\text { limit }\end{array}$ \\
\hline & $\begin{array}{l}\text { Mean Proximity Index } \\
\text { (PROX_MN) }\end{array}$ & $\begin{array}{c}\text { Measures the isolation degree of units } \\
\text { and the fragmentation level }\end{array}$ & Meters & $\mathrm{PROX} \geq 0$ \\
\hline & $\begin{array}{c}\text { Interspersion and } \\
\text { juxtaposition index } \\
\text { (IJI) }\end{array}$ & $\begin{array}{l}\text { Represents the patches relative } \\
\text { interspersion in landscape level. }\end{array}$ & Percent & $\begin{array}{c}0<\mathrm{IJI} \leq \\
100\end{array}$ \\
\hline \multirow{2}{*}{ 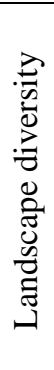 } & $\begin{array}{l}\text { Shannon's Diversity } \\
\text { Index (SHDI) }\end{array}$ & Measures the diversity of landscape. & Unitless & $\begin{array}{l}\text { SHDI } \geq 0, \\
\text { without } \\
\text { limit }\end{array}$ \\
\hline & $\begin{array}{l}\text { Simpson's Diversity } \\
\text { Index (SIDI) }\end{array}$ & $\begin{array}{l}\text { This metric is more susceptible than } \\
\text { Shannon's diversity metrics about } \\
\text { abundant patches representing the } \\
\text { probability that any } 2 \text { pixels selected at } \\
\text { random would be different patch types }\end{array}$ & Unitless & $0 \leq \mathrm{SIDI}<1$ \\
\hline
\end{tabular}

Source: [6]

The methods employed in this study are specific to both geography and other sciences, conferring an interdisciplinary character to the present paper: the analysis method (causeeffect analysis, statistical analysis and correlation of the landscape metrics results); the method of synthesis (used for the centralization and final analysis of the data obtained from the computation of landscape metrics); geospatial mapping and geospatial analysis in GIS (for spatial representation of the Corine Land Cover datasets).

In order to process CORINE Land Cover datasests and resulted vector data, we used several software programs: ArcGIS 10.2.2 software for raster analysis and mapping of geographical data, FRGSTATS 4.2 software for landscape metrics selection and processing and Microsoft Office Excel 2016 for graphical representation.

\section{RESULTS}

\section{Analysis of the extent and intensity of land use and land cover changes}

According to the system classification adopted, time series of land use land cover maps of three periods under study were developed and are presented in Figure 3. We used the legend third level (maximum disaggregation of data), resulting a number of 20 land cover classes for 1990 and 2000, and 18 land cover classes for 2006 and 2012. Alongside the diachronic spatial distribution of land use classes, the analysis was completed by generating the percentage of each class of use within the boundary of Suceava drainage basin on Romanian territory (Table 2), the percentage change and the annual change rate of each land cover categories (Table 3 ). 

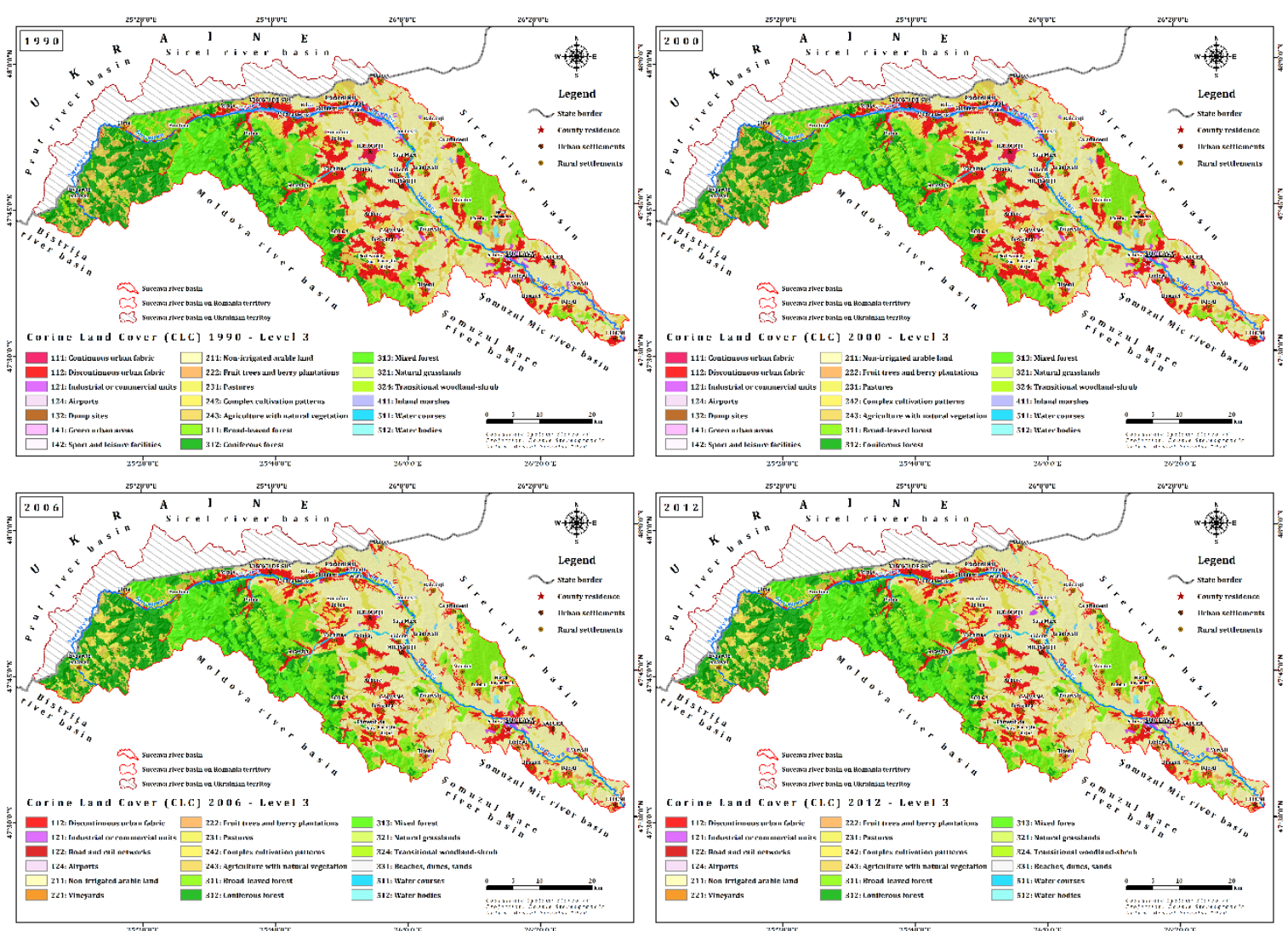

Figure 3. Spatial distribution of land cover classes in 1990, 2000, 2006 and 2012

At the level of the entire study area, just eight land cover/use classes cover more than $3 \%$ of the Suceava River Basin: non-irrigated arable land, coniferous forest, discontinuous urban fabric, mixed forest, broad-leaved forest, agriculture in combination with natural vegetation, pastures and complex cultivation patterns (Table 2). Thus, we can notice that the landscape of Suceava drainage area is dominated by three major landscapes: agricultural $(47 \%)$, forest $(35 \%)$, and urban (13\%). Semi-natural areas and landscapes defined by wetland and water areas $(5 \%)$ complete the general structure of the landscape from the Suceava hydrographic basin (Table 2).

The results emphasize that non-irrigated arable land landscape covered the greatest area of Suceava River Basin and throughout the all time horizons investigated (from 27.93\% in 1990, 28.26\% in 2000 to over 32\% in 2006 and 2012). Coniferous forest covered over $13 \%$ of the entire basin throughout the all time horizons investigated, whereas discontinuous urban fabric covered about $13 \%$ of the total study area in 1990 and 2000 and broad-leaved forest covered about $11.50 \%$ in 2006 and 2012, respectively. Even if non-irrigated arable land gained the greatest area in hectares (758 ha in 1990-2000 and 9540 ha in 2000-2006), the biggest values of the change rate for all periods analyzed have been registered by natural grasslands $(859.26 \%)$, as a result of the conversion of other land use and land cover classes in this type of land cover. The highest values of change rate were registered by water bodies $(-21.99 \%)$ with an annual decreasing rate of 2.20 ha/year (Table 3).

Excepting natural grasslands which recorded the highest values of change rate for all periods under investigation, the analysis offered a different situation regarding the values of change rate for all time horizons take into account. Thus, for the first analyzed period (1990-2000), the biggest values of the change rate were registered for dump sites class (- 
$39.74 \%$ ), that means an annual loss of $3.97 \mathrm{ha} /$ year. The second greatest change rate was registered by fruit trees and berry plantations (-37.84\%) with an annual loss of 3.78 ha/year. The biggest positives values of percentage change were registered for transitional woodland-shrub class, namely $8.36 \%$ with an annual increasing rate of 0.84 ha/year (Table 3).

Table 2. Total area in expressed hectares and percentage accounted for each land use and land cover categories present in the study area

\begin{tabular}{|c|c|c|c|c|c|c|c|c|}
\hline \multirow{2}{*}{ Land cover/Land use class } & \multicolumn{2}{|c|}{1990} & \multicolumn{2}{|c|}{2000} & \multicolumn{2}{|c|}{2006} & \multicolumn{2}{|c|}{2012} \\
\hline & $\mathrm{Ha}$ & $\%$ & $\mathrm{Ha}$ & $\%$ & $\mathrm{Ha}$ & $\%$ & $\mathrm{Ha}$ & $\%$ \\
\hline Continuous urban fabric & 440 & 0.19 & 441 & 0.19 & - & - & - & - \\
\hline Discontinuous urban fabric & 29546 & 12.95 & 29605 & 12.98 & 23951 & 10.50 & 24003 & 10.52 \\
\hline Industrial or commercial units & 1812 & 0.79 & 1859 & 0.82 & 860 & 0.38 & 987 & 0.43 \\
\hline Road and rail networks and associated land & & & & & 50 & 0.02 & 50 & 0.02 \\
\hline Airports & 38 & 0.01 & 38 & 0.01 & 22 & 0.01 & 22 & 0.01 \\
\hline Dump sites & 78 & 0.03 & 47 & 0.02 & - & - & - & - \\
\hline Green urban areas & 52 & 0.02 & 53 & 0.02 & - & - & - & - \\
\hline Sport and leisure facilities & 26 & 0.01 & 26 & 0.01 & - & - & - & - \\
\hline Non-irrigated arable land & 63698 & 27.93 & 64456 & 28.26 & 73996 & 32.44 & 73886 & 32.39 \\
\hline Vineyards & - & - & - & - & 43 & 0.02 & 43 & 0.02 \\
\hline Fruit trees and berry plantations & 954 & 0.42 & 593 & 0.26 & 726 & 0.32 & 726 & 0.32 \\
\hline Pastures & 13976 & 6.13 & 13641 & 5.98 & 19627 & 8.61 & 19558 & 8.58 \\
\hline Complex cultivation patterns & 8589 & 3.77 & 8652 & 3.79 & 10649 & 4.67 & 10647 & 4.67 \\
\hline Agriculture with natural vegetation & 19973 & 8.76 & 19835 & 8.70 & 9540 & 4.18 & 9540 & 4.18 \\
\hline Broad-leaved forest & 24152 & 10.59 & 24321 & 10.66 & 26213 & 11.49 & 26214 & 11.49 \\
\hline Coniferous forest & 30578 & 13.41 & 29965 & 13.14 & 30451 & 13.35 & 30437 & 13.34 \\
\hline Mixed forest & 25113 & 11.01 & 25207 & 11.05 & 26619 & 11.67 & 26634 & 11.68 \\
\hline Natural grasslands & 27 & 0.01 & 27 & 0.01 & 259 & 0.11 & 259 & 0.12 \\
\hline Transitional woodland-shrub & 4057 & 1.78 & 4396 & 1.93 & 1659 & 0.73 & 1660 & 0.73 \\
\hline Beaches, dunes, sands & - & - & - & - & 78 & 0.03 & 77 & 0.03 \\
\hline Inland marshes & 2506 & 1.10 & 2510 & 1.10 & - & - & - & - \\
\hline Water courses & 2205 & 0.97 & 2210 & 0.97 & 3108 & 1.36 & 3108 & 1.36 \\
\hline Water bodies & 282 & 0.12 & 220 & 0.10 & 251 & 0.11 & 251 & 0.11 \\
\hline Total & 228102 & 100 & 228102 & 100 & 228102 & 100 & 228102 & 100 \\
\hline
\end{tabular}

The 2000-2006 period highlights that four land cover-use classes have totally converted in other land cover/use categories: dump sites, green urban areas, sport and leisure facilities and inland marshes. Other land cover/use classes that registered considerable decreasing rates during the 2000-2006 period were: transitional woodland-shrub ($62.26 \%)$, industrial or commercial units $(-53.84 \%)$, land principally occupied by agriculture $(-51.90 \%)$, airports $(-42.11 \%)$ and discontinuous urban fabric $(-19.10 \%)$. In contrast, the pastures class experienced the greatest gains of area (5986 ha) from 2000 to 2006, which means a percentage change of $43.88 \%$ and an annual increasing rate of 7.31 ha/year. Other land cover/use classes that registered considerable increasing rates during the 2000-2006 time horizon were: water courses (40.63\%), non-irrigated arable land $(14.80 \%)$ and water bodies (14.09\%).

The last period analyzed (2006-2012) emphasizes a relative stability of land use system in the studied area. In line with this statement, the biggest values of change area (positive trend) was registered by industrial or commercial units (127 ha), so a percentage change of $14.77 \%$ that means an annual increasing rate of 2.46 ha/year and by discontinuous urban fabric which gained an area of 52 ha $(0.22 \%$; 0.04 ha/year). The other side, the biggest values of change area (negative trend) was registered for non-irrigated arable land with a lost area of 110 ha, so a percentage change of $0.15 \%$ that means an annual decreasing rate of $0.02 \mathrm{ha} /$ year. Pastures have also registered high values of change area (-69 ha) with a total percentage change of $0.35 \%$ (-0.06 ha/year). 
Table 3. Change in area, extent and rate of change over the three time horizons analyzed

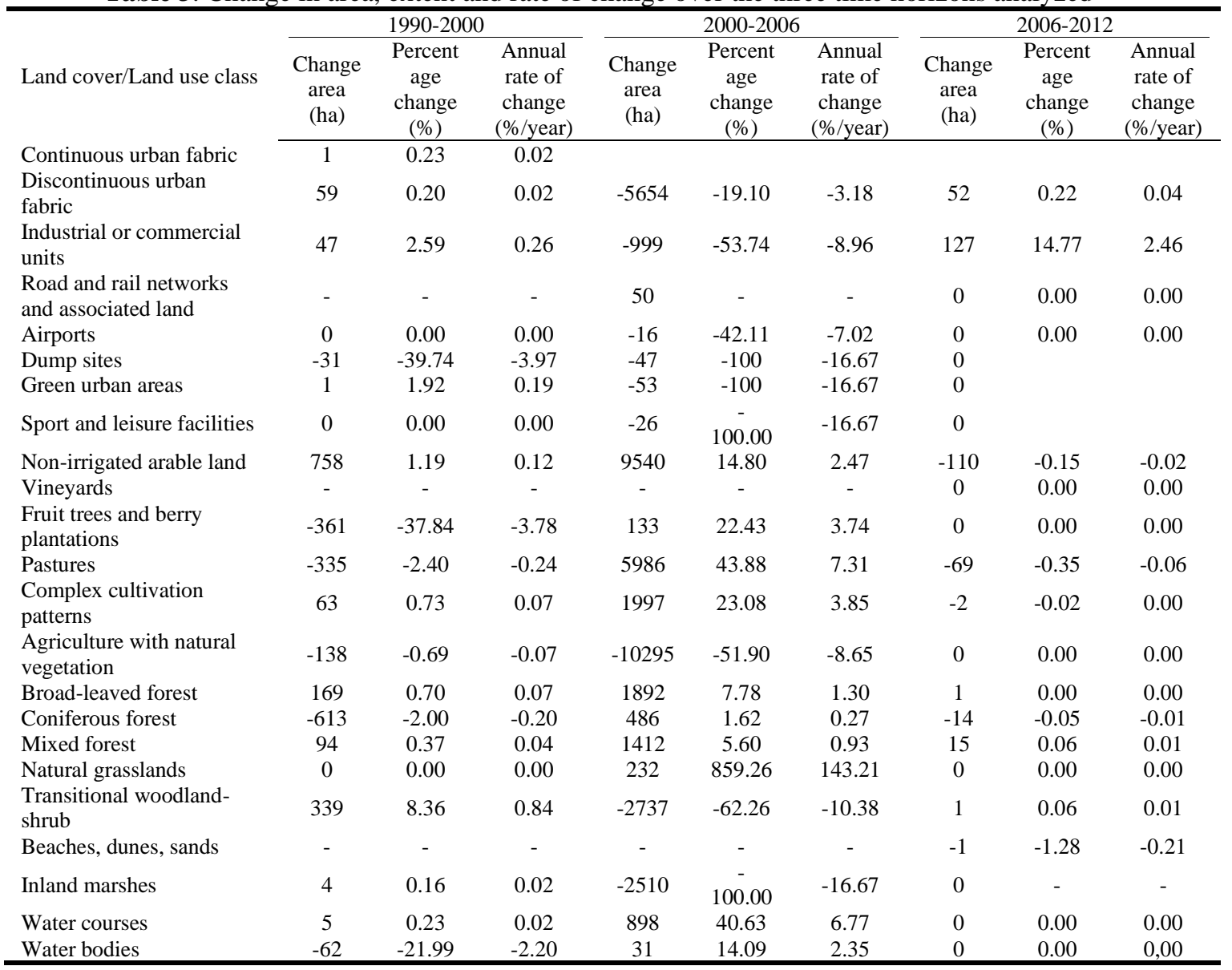

\section{Class level analysis of landscape metrics}

Every landscape can be characterized by its structure or composition, the spatial arrangements of the constituent elements, the shape of plots and not ultimately by the diversity or the abundance. The landscape of the study area is dominated by forest, agriculture and urban pattern, but exist also other land cover/use categories which contribute to the landscape diversity as a consequence of dynamics in space and time.

\section{Analysis of landscape composition}

For the analysis of landscape composition we employed four landscape metrics at class level, namely: number of patches, mean patch area, edge density and largest patch index, as they are shown in Figure 4.

The number of patches (Figure 4 - a) is a simple measure of the extent of subdivision or fragmentation of the landscape pattern. Moreover, when you used the same landscape in different time periods, this indicator is suitable to reveal the level of landscape fragmentation. In detail, the number of patches ranged from a minimum of 1 patches (vineyards, sport and leisure facilities or green urban areas) to a maximum of 245 patches (pastures) or over one hundred patches (complex cultivation patterns, agriculture with natural vegetation, discontinuous urban fabric or broad-leaved forest).

To enhance the degree of fragmentation, we combined this index with mean patch area (Figure 4 - b), because an increase in the number of patches will cause a decrease of mean patch size and vice versa. In line with this statement, we noticed that a decrease of the number of patches from 88 in 1990 to 80 in 2012 caused an increase of the mean shape 
area from 723.85 ha in 1990 to 923.58 ha in 2012 for non-irrigated arable land. We have to mention that the mean patch area is also determined of the total area of individual land cover class.

Similar information with respect to landscape fragmentation is offered by edge density (Figure 4 - c) which it is an expression of the form and complexity of a class's patches as well as of the heterogeneity of the mosaic that constitutes the whole landscape. The index is dependent also by the total class area or how much the respective plots are bound to specific, more compact portions of the territory. In our case study, the edge density ranges from $9.76 \mathrm{~m} / \mathrm{ha}$ in 2012 for non-irrigated arable land to $0.1 \mathrm{~m} / \mathrm{ha}$ for sport and leisure facilities in 1990 and 2000.
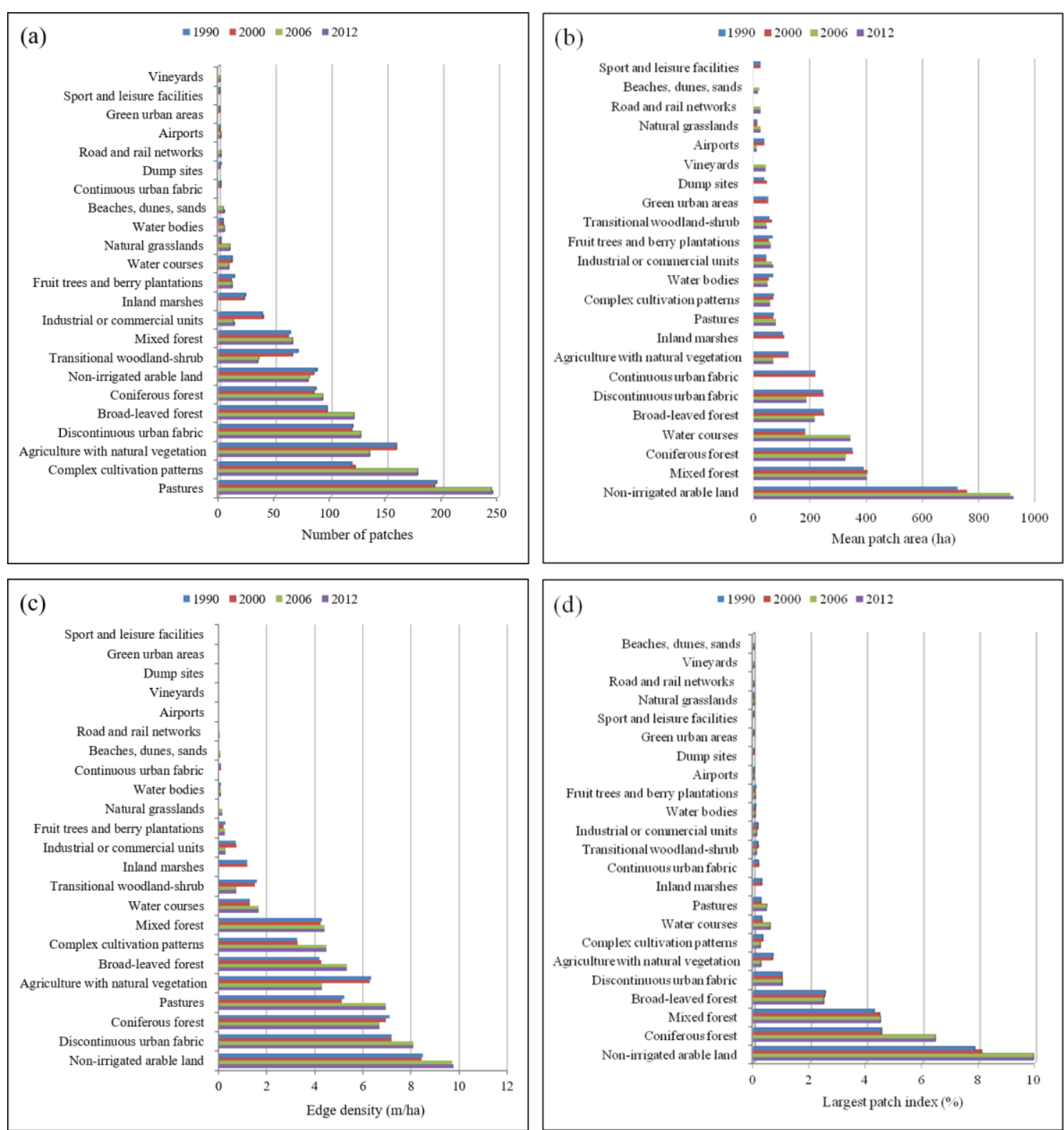

Figure 4. Composition metrics: number of patches (a), mean patch area (b), edge density (c) and largest patch index (d)

The last index which we employed for the analysis of landscape composition at class level was largest patch index (Figure 4 - d) which shows the percentage of total landscape area comprised by the largest patch. This index is easy to compare to the total class area and 
it varies among $0 \%$ to $100 \%$ when the landscape is composed by a single patch. The largest patch index is minimum $(0.2 \%)$ for beaches, dunes and sands, vineyards and road and rail networks as a consequence of the total small area of the classes. In contrast, the highest values of the largest patch index were registered for non-irrigated arable land (7.86\% in 1990 and $9.95 \%$ in 2012) and by coniferous forest, mixed forest, broad-leaved forest and discontinuous urban fabric, these being the classes which occupy the high percentage of the study area.

\section{Landscape shape}

The second category of indicators that we take into analysis involved those that highlight the landscape shape: mean patch shape (Figure 5 - e) and perimeter-area fractal dimension (Figure 5 - f). The mean shape index indicates the average form of units with different land cover/use categories. The most of classes present nearly a rectangular shape because provide values which range between 1.16 and 1.90. The classes with values higher than 1.90 present a distinctly elongated irregular shape. Sport and leisure facilities class reveals almost a circular shape, while vineyards present almost a square shape.

The other side, the perimeter-area fractal dimension shows the complexity of the perimeter of a vegetation unit. This index shows that the most of classes registered values below 1.50 that means a relatively small complexity of the patches in form). The values of this index range from 1.33 for transitional woodland-shrub in 2000 to 1.69 for water courses in 1990. During the three time intervals investigated we observed an upward trend since 2000-2006 intervals with the exception of coniferous and mixed forests which registered an insignificant decrease.
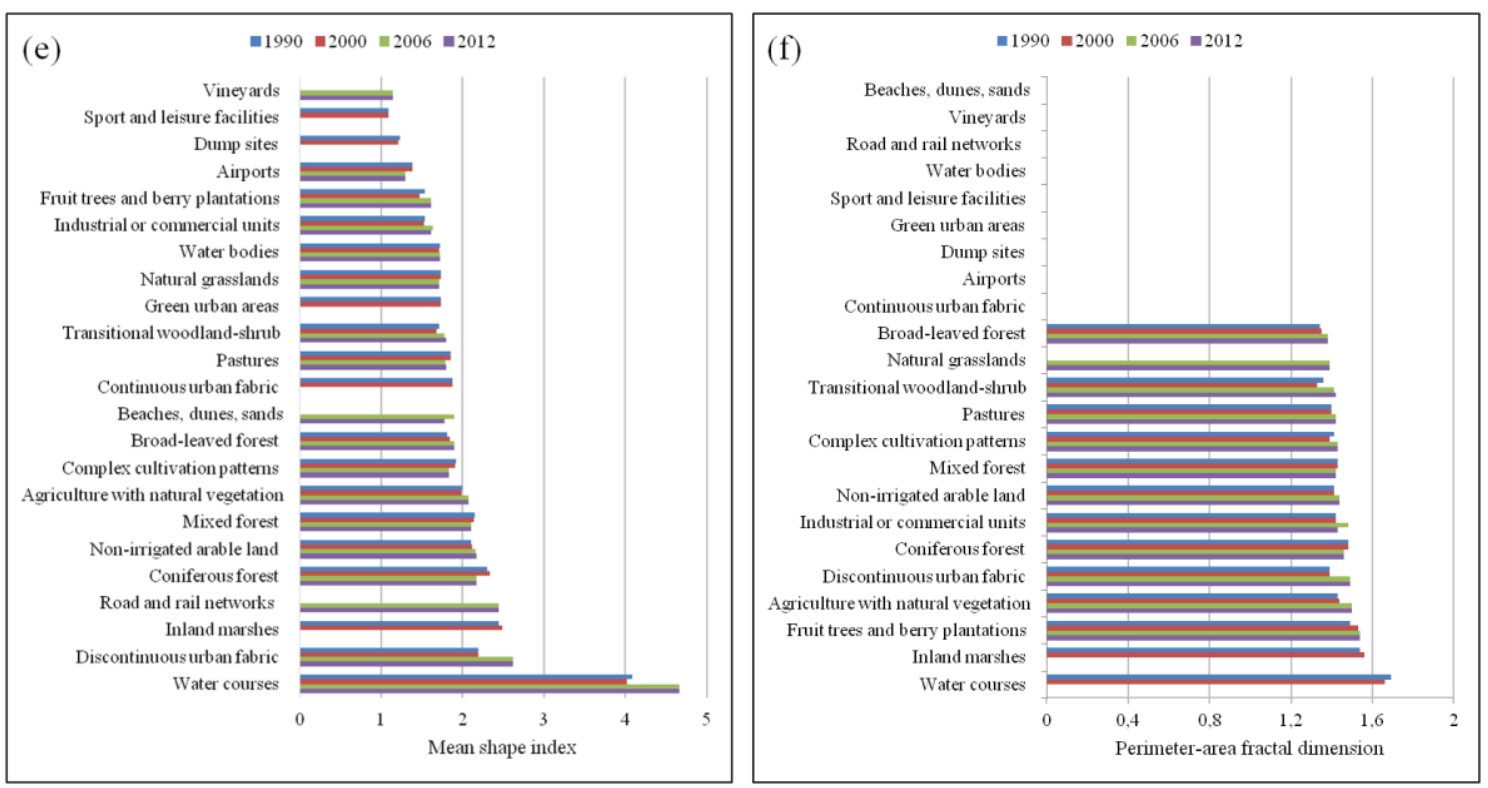

Figure 5. Shape metrics: mean shape index (e) and perimeter-area fractal dimension (f)

\section{Landscape configuration}

The third category of landscape metrics applied at class level emphasizes the landscape configuration. In particular, we chose four landscape metrics for the analysis of the spatial arrangements of the patches corresponding to a class, as they are presented n Figure 6. First of these indices is represented by landscape shape index (Figure 6 - g) which shows the form of patches. The landscape shape index is equal to 1 when the landscape elements consist of a square or almost square polygon and it increases up to infinite values when 
the shape of the landscape patches become more irregular. The smallest values of this indicator registered by sport and leisure facilities (1.09), so the shape of the constituent patches is almost a square. In contrast, the discontinuous urban fabric reached the highest value of this index (30.04 in 2012). The most of classes present an irregular form according to the interpretation of values of landscape shape index. Moreover, the index show the degree of the compactness. Further, the arrangement of the patches and the type of distribution (uniform or irregular) is proved by interspersion and juxtaposition index (Figure $6-\mathrm{h}$ ). This index approaches zero when adjacencies are unevenly distributed and gains 100 if all patch types are equally adjacent to all other patch types. In our study area, the most of land cover classes registered values which ranged between $50 \%$ and $70 \%$, the smallest value being registered by airports (15.54\% in 2006 and 2012) whereas the highest value was recorded by transitional woodland-shrub (73.49\% in 2006).
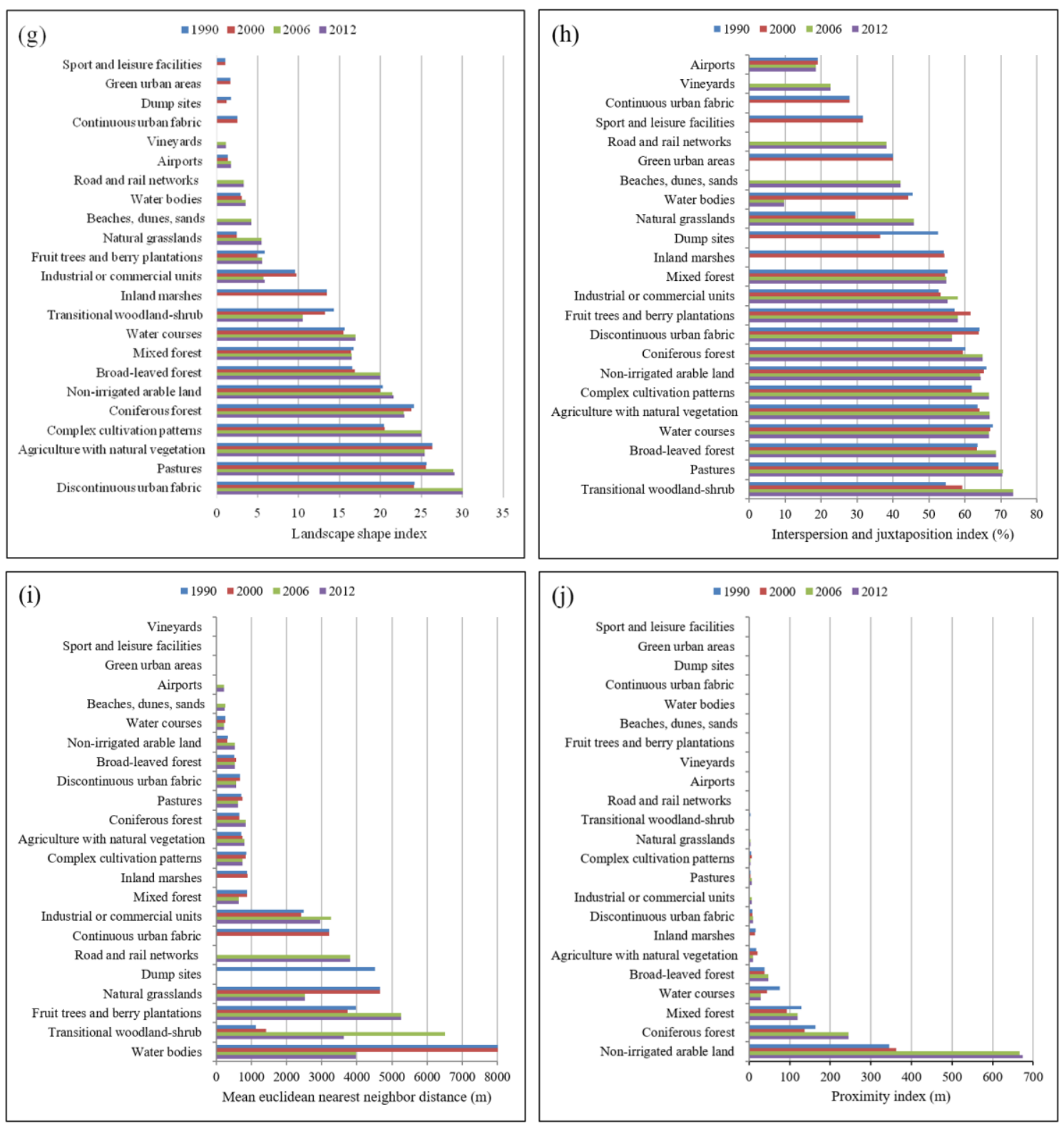

Figure 6. Configuration metrics: landscape shape index (g) interspersion and juxtaposition index (h), mean Euclidean nearest neighbor distance (i) and proximity index (j) 
The last two indices analyzed, the mean Euclidean nearest neighbor distance (Figure 6 i) and the proximity index (Figure $6-\mathrm{j}$ ) present information about the distance between patches and measures the degree of isolation and fragmentation. The following classes registered increases over the time horizons analyzed: transitional woodland-shrub, fruit trees and berry plantations, industrial or commercial units, mixed forest, agriculture with natural vegetation or coniferous forest. That means that the patches corresponding to these classes became more isolated. The other side, in the case of proximity index we have chosen a radius defined by 200 meters, this fact explaining why some classes have not values for this index. The reduction in the isolation of patches (small values of the mean Euclidean nearest neighbor distance) increases the proximity index (high values of the proximity index shows that the patches become closer), behavior specific to the natural grasslands, pastures or mixed forest.

\section{Landscape level analysis of landscape metrics}

The second phase of our analysis aimed to investigate land use and land cover changes by the application of several landscape metrics (those applied at class level and two metrics of diversity). The indices employed were divided into four categories in order to describe landscape composition, shape, configuration and diversity (Table 4 and Table 5 show the statistical results of these metrics).

Table 4. Landscape metrics quantification at landscape level (composition and shape)

\begin{tabular}{|c|c|c|c|c|c|c|}
\hline \multirow[b]{2}{*}{ Year } & \multicolumn{4}{|c|}{ Composition } & \multicolumn{2}{|c|}{ Shape } \\
\hline & NP & AREA_MN (ha) & $\mathrm{ED}(\mathrm{m} / \mathrm{ha})$ & $\overline{L P I}(\%)$ & MN_SHAPE & PAFRAC \\
\hline 1990 & $\overline{1102}$ & 206.99 & 25.73 & 7.86 & 2.00 & 1.42 \\
\hline 2000 & 1086 & 210.04 & 25.50 & 8.10 & 2.00 & 1.42 \\
\hline 2006 & 1139 & 200.27 & 26.64 & 9.95 & 2.03 & 1.45 \\
\hline 2012 & 1140 & 200.09 & 26.68 & 9.95 & 2.03 & 1.45 \\
\hline
\end{tabular}

The analysis emphasizes that it can be identified two major trends of landscape pattern evolution. Firstly, during 1990-2000 period we noticed a small decrease of the degree of fragmentation, consequence of reducing the number of patches from 1102 in 1990 to 1086 in 2000. This fact determined increases in the mean patch area and in the largest patch index. The shape index presented constant values ( 2 for mean shape index and 1.42 for perimeter-area fractal dimension) between 1990 and 2000, showing an irregular shape of the patches. Moreover, the reduction of fragmentation is prove by the growing values of the contagion index which highlight the level of interspersion and aggregation (zero when the classes are disaggregated to the maximum and equals to 100 when all the classes are aggregated at most, i.e., when the landscape is composed of one patch). The increase of the mean Euclidean nearest neighbor distance from $984.48 \mathrm{~m}$ in 1990 to $999.65 \mathrm{~m}$ in 2000 and the reduction of the proximity index (defined the same radius of $200 \mathrm{~m}$ ) from the $57.22 \mathrm{~m}$ in 1990 to $53.89 \mathrm{~m}$ in 2000, respectively, support the compactness of the landscape alongside landscape shape index. This type of evolution given by the fact that patches became sparsely and the probability that two patches from the same class to be closer is small support the irregularity of spatial distribution.

Secondly, starting with the year 2006 we identify an increase in the level of landscape fragmentation, as a result of the increase in the number of patches from 1086 in 2000 to 1140 in 2012. This evolution caused a decrease of the mean patch area from 210.04 ha in 2000 to 200.09 ha in 2012 and an increase of the edge density from $25.50 \mathrm{~m} / \mathrm{ha}$ in 2000 to $26.68 \mathrm{~m} / \mathrm{ha}$ in 2012 . The shape of the patches registered small increases but the form 
remained irregular. The higher values of contagion index and interspersion and juxtaposition index indicate a more uniformly configuration of the landscapes, because the patches were more regularly distributed across the study area.

Table 5. Landscape metrics quantification at landscape level (configuration and diversity)

\begin{tabular}{|c|c|c|c|c|c|c|c|}
\hline \multirow[b]{2}{*}{ Year } & \multicolumn{5}{|c|}{ Configuration } & \multicolumn{2}{|c|}{ Diversity } \\
\hline & CONTAG $(\%)$ & LSI & IJI (\%) & ENN_MN (m) & PROX_MN (m) & SHDI & SIDI \\
\hline 1990 & 54.16 & 33.03 & 66.45 & 984.48 & 57.22 & 2.13 & 0.85 \\
\hline 2000 & 54.37 & 32.75 & 66.28 & 999.64 & 53.89 & 2.13 & 0.85 \\
\hline 2006 & 54.46 & 34.11 & 66.74 & 923.19 & 83.87 & 2.01 & 0.83 \\
\hline 2012 & 54.40 & 34.16 & 66.76 & 922.33 & 83.82 & 2.02 & 0.83 \\
\hline
\end{tabular}

The analysis of the landscape diversity is based on the results of two different landscape metrics: Shannon's Diversity Index (SHDI) and Simpson's Diversity index (SIDI $\div$ Table 5). The Shannon's Diversity Index measures the ecological diversity in a population but can also be applied to the landscape investigation. There is not diversity when a landscape contains a single patch (its value is zero); as the different patches and their spatial distribution increase, diversity also grows. In contrast, another popular index that measures the landscape diversity, similar to the SHDI but with a more intuitive interpretation, is the SIDI. Precisely, the SIDI is given by the probability that two randomly selected landscape points are different types of patches. The numerical value of SIDI varies from 0 to 1 [2]. SIDI is a dominance index, which is weighted toward the abundance of the most common land use category [36]. A little reduction in the values of SHID and SIDI was observed after 2000 as a consequence of the less uniformity in the distribution of land cover classes and the domination of large patches of a few land cover and use categories.

\section{DISCUSSIONS}

Today, cause of the widespread recognition that landscape is a dynamic entity, one of greatest challenge confronting landscape pattern analysis is quantifying temporal variation in landscape pattern metrics [37].

During the last decades, the Suceava River Basin experienced several changes in the socio-economic conditions starting with transition to the market economy and ending with post-accession period to the European Union. Moreover, the different agricultural and environmental policies that have occurred over the las years have led to significant changes in the spatial land cover and land use pattern.

Another research direction to identify the level of change in the landscape is represented by the Landscape Change Index (LCI), which was defined by Woodward and Fuhlendorf [38] as the total change in vegetation and land use at the landscape level by combining the absolute average changes of all land-cover types into one value. In this way, the Landscape Change Index is described by one value which is the result of all types of changes taking place in the background of the landscape in a given period of time. The main step for the calculation of the LCI consists of determining the level of percentage deviation between the reference criterion and data from next time interval, for each category of the landscape structure [39].

According to the applicability of Landscape Change Index, we identified in which period the changes were most intense. Thus, we noticed that the second analyzed period was the most intense in terms of change receiving a value of 18.46 being followed by the first analyzed period with a value of 1.34. The highest value of the LCI in the second analyzed period can be explained by the high rates of conversion at the level of several classes, which determined an intensification and extensification of the agriculture and can be the 
effect of the implementation of new regulations of the Common Agricultural Policies starting with 2000 (Agenda 2000) and 2003. If we take into account the changes between the classes that are not present in the same years of investigation, the level of LCI increases up 19.68 .

The first analyzed period registered also a high level of LCI as a consequence of transition period from centralized economy to the market economy, which implemented new rules on the property right (Law no. 58/1991), or the permissive legislation on construction sector and the right to free movement of persons.

The third analyzed period registered the smallest value (0.18) of LCI and can be explained by the strong homogenization of land use/cover classes (small rates of changes) and as a result of increasing stability after post-accession to the European Union.

The changes in economic conditions, depopulation, ageing of population, frequent changes in legislation have led to the abandonment of agricultural lands in other areas and the subsequent process of re-naturalization. Although there are many factors which affect the behavior of landscape metrics like as the number of land use classes, the scale, both grain and extent, the statistical approach used for determining neighborhood (e.g., the four neighbor rule versus eight-neighbor rule), the landscape metrics chosen for this study reveal valuable information about the landscape changes and processes.

\section{CONCLUSIONS}

In the context of a variety of existing tools, plug-ins or extensions which range from descriptive tools to modelling tools that provide a technical support to create artificial landscape patterns modelling under certain conditions, the present paper quantified the changes in landscape spatial pattern by the application of ArcGis software, FRAGSTATS software and MS Excel spreadsheets in order to produce, process and present valuable information about the changes in landscape structure within the Suceava River Basin.

With the aim to assess land cover and land use changes in the Suceava River Basin on Romanian territory we applied an interdisciplinary approach by integrating territorial mapping and landscape ecological perspectives. The analysis was based on CORINE Land Cover datasets using the third level of hierarchical classification scheme and was caried out for three time horizons, namely 1990-2000, 2006-2006 and 2006-2012, each period corresponding of specific stages of evolution of the Romania's historical background: transition period to the market economy, pre-accession period to the European Union and post-accession period to the European Union, respectively.

The application of the landscape metrics used in the present study offer the posibility to indentify not only the quantitative results about land cover or use categoires, but also have allowed us to quantify the active process that have occcured and occurs at the level of the Suceava River Basin, namely the fragmentation degree.

We have identified that the driving forces which caused changes in land cover and land use spatial pattern were measures and activities that were part of the political agendas, historical-cultural evolution, technological and economic level, demographic factors and not ultimately of the natural conditions which shapes the local landscape.

The geographical tools could prove their usefulness because offer an overview of the territory and support the implementation of the appropriate measures that can guarantee a dynamic decision support system used to develop strategies and to sustain landscape planning.

The future research will concern the application of other techniques and tools, the improvement of data quality, the integration of historical cartography and aerial 
photographs and, above all, the quantification of the stability of landscape or the intensity of land use changes and the processes occurred in relation with natural conditions, land use policies in different socio-economic contexts.

\section{REFERENCES}

[1] Dannebeck, S., Hoppe, A., Küster, H., \& McCracken, D. Factors affecting cultural landscapes: An overview. In K. Krzywinski, M. O'Connell, \& H. Küster (Eds.), Cultural landscapes of Europe. Fields of Demeter, Haunts of Pan, Aschenbeck Media, pp. 47-54, 2009.

[2] Statuto, Dina, Cillis, G., \& Picuno, P. GIS-based Analysis of Temporal Evolution of Rural Landscape: A Case Study in Southern Italy. Natural Resources Research. 2018. DOI: 10.1007/s11053-018-9402-7.

[3] Forman, R. T. T., \& Godron, M. Landscape ecology. NewYork: Wiley, 620 pp., 1986.

[4] Urban, D. L., O’Neill, R. V., \& Shugart, H. H. J. Landscape ecology: A hierarchical perspective can help scientists understand spatial patterns. Bioscience, 1987.

[5] Uuemaa, E., Mander, Ü, \& Marja, R. Trends in the use of landscape spatial metrics as landscape indicators: A review. Ecological Indicators, vol. 28, pp. 100-106, 2013. DOI: 10.1016/j.ecolind.2012.07.018.

[6] McGarigal, K., Cushman, S.A., Neel, M.C. \& Ene, E. FRAGSTATS: spatial pattern analysis program for categorical maps, 3.1st edn. University of Massachusetts, Amherst: 2002.

[7] MacLean, M. G., \& Congalton, R. G. (2013) PolyFrag: a vectorbased program for computing landscape metrics, GIScience \& Remote Sensing, vol. 50 (6), pp. 591-603. DOI: $10.1080 / 15481603.2013 .856537$

[8] DeZonia, B., and Mladenoff, D. J. "IAN 1.0.23." Department of Forest Ecology \& Management, University of Wisconsin, Madison, WI. 2004.

[9] Mladenoff, D. J. \& DeZonia, B. APACK 2.0 User's Guide. Department of Forest Ecology and Management, University of Wisconsin Madison, Madison, WI, USA, 1997

[10] Saura, S., \& Torné, J. "Conefor Sensinode 2.2: A Software Package for Quantifying the Importance of Habitat Patches for Landscape Connectivity." Environmental Modelling \& Software, vol. 24, pp. 135-139, 2009.

[11] Zaragozí, B., Belda, A., Linares, J., Martínez-Pérez, J. E., Navarro, J.T. \& Esparza P., J. A free and open source programming library for landscape metrics calculations. Environmental Modelling and Software, vol. 31, pp. 131-140, 2012. DOI: 10.1016/j.envsoft.2011.10.009.

[12] Rempel, R., Carr, A. \& Elkie, P. Patch analyst for ArcGIS. Centre for Northern Forest Ecosystem Research, Ontario Ministry of Natural Resources. Lakehead University, Thunder Bay, 2008.

[13] Eastman, J. IDRISI Selva. Clark University, Worcester, MA, 2012.

[14] Zhai, R., Li, W., Zhang, C., Zhang, W. \& Wang, W. The transiogram as a graphic metric for characterizing the spatial patterns of landscapes. Landscape Ecology. 2018. DOI: 10.1007/s10980-018-0760-7.

[15] Walz, U. \& Hoechstetter, S. "LandMetrics-3D" - Landscape metrics for raster-based structure analysis in three dimensions. IALE-D Jahrestagung, 2008.

[16] Lang, S., Klug, H. Interactive Metrics Tool (IMT) - a didactical suite for teaching and applying landscape metrics. Ekológia (Bratislava, vol. 25, Supplement 1, pp. 131-140, 2006.

[17] Schreiber, W., Drăguț, L. \& Man, T. Analysis of the geographical landscapes in the western part of the Transylvanian Plain, Cluj University Press, Cluj-Napoca, 135 pp., 2004. [in Romanian]. 
[18] Olaru (Barnoaiea), Adriana Roxana. The dynamic of the landscape in two representative areas in Neamţ and Suceava counties. Ph.D. Thesis, Ștefan cel Mare University of Suceava, Faculty of Forestry, Doctoral School of Applied and Engineering Sciences, Suceava, 163 pp., 2011. [in Romanian].

[19] Cîmpianu, C. \& Corodescu, E. 2013. Landscape dynamics analysis in Iaşi Metropolitan Area (Romania) using remote sensing data. Cinq Continents, vol. 3 (7), pp 18-32. [Available online] URL: http://www.cinqcontinents.uv.ro/3/3_7_Cimpianu.pdf [Accessed 21.10.2019].

[20] Corpade, C., Man, T., Petrea, D., Corpade, A.M. \& Moldovan, C. Changes in landscape structure induced by transportation projects in Cluj-Napoca periurban area using GIS, Carpathian Journal of Earth and Environmental Sciences, vol. 4 (9), pp. 177-184, 2014.

[21] Pătru-Stupariu, Ileana, Stupariu, M. S., Cuculici, Roxana \& Huzui, Alina. Application of the global indicators to landscape change modeling on Prahova Valley (Romanian Carpathians and Subcarpathians). International Journal of the Physical Sciences, vol. 6(3), pp. 534-539, 2011.

[22] Horodnic, V.-D., Bistricean P.-I., Mihăilă, D \& Efros, V. Assessment of land use changes and landscape fragmentation in the tourism area of Cacica and Vatra Dornei. In Georeview: Scientific Annals of Stefan cel Mare University of Suceava. Geography Series. International Conference Atmosphere and Hydrosphere, $3^{\text {rd }}$ edition, 2018, Vatra Dornei, Romania.

[23] Niculae, M.-I. \& Pătroescu, Maria. Quantifying forest Ecosystems Fragmentation in the Subcarpathians between the Râmnicu Sărat and the Buzău Valleys, Romania, using Landscape Metrics, Geographical Phorum. Geographical Studies and Environmental Protection Research, vol. 10 (1), pp. 187-194, 2011.

[24] Vorovencii, I. Quantifying landscape pattern and assessing the land cover changes in Piatra Craiului National Park and Bucegi Natural Park, Romania, using satellite imagery and landscape metrics. Environmental Monitoring and Assessment, vol. 187 (11), 2015. DOI: 10.1007/s10661015-4909-4.

[25] Corpade, C., Bădărău, Al. S., Corpade, Ana-Maria, Hognogi, Gh., Pop, Simona \& Banc, S,tefana. Changes in landscape metrics induced by deforestation in ROSCI0358 Pricop-HutaCerteze Nature 2000 site. STUDIA UBB GEOGRAPHIA, LXI, 2, pp. 53-61, 2016.

[26] Corpade, C., Nicolin, Alma Lioara, Corpade, Ana-Maria \& Arsene G.-G. Changes in the spatial structure of landscape within the site of community interest ROSCI0233 Someșul Rece. Research Journal of Agricultural Science, 48 (2), pp. 21-28, 2016.

[27] Ianăş, Ana-Neli \& Germain, D. Quantifying landscape changes and fragmentation in a nationl park in the Romanian Carpathians. Carpathian Journal of Earth and Environmental Sciences, vol. 13 (1), pp. 147-160, 2018.

[28] Oprea-Gancevici, D.-I. Suceava Valley - geomorphological study. Ph.D. Thesis, "Ştefan cel Mare" University of Suceava, Faculty of History and Geography, Doctoral School of Applied and Engineering Sciences, Suceava, 270 pp., 2014. [in Romanian].

[29] Porcuțan, Adriana Mihaela. River water flow in Suceava hydrographic basin. Ph.D. Thesis, "Babeș-Bolyai" University, Faculty of Geography, Geography Doctoral School, Cluj-Napoca, 175 pp., 2018. [in Romanian].

[30] Birsan, M.-V., Dumitrescu, A. (2014), ROCADA: Romanian daily gridded climatic dataset (1961-2013) V1.0, National Meteorological Administration, Bucharest, Romania, DOI: 10.1594/PANGAEA.833627.

[31] Tănasă, I. The climate of the Suceava Plateau - Risk phenomena and implications for sustainable development. Ph.D. Thesis, "Ştefan cel Mare" University of Suceava, Faculty of History and Geography, Doctoral School of Applied and Engineering Sciences, Suceava, 257 pp., 2011. [in Romanian]. 
[32] Clinovschi, F. The Distribution of the Wooden Forest Species in the Hydrographic Basin of the Suceava. Annals of the University of Oradea, Forestry Series, vol. 9 (9), Oradea University Publishing House, pp. 41-48, 2004.

[33] Cocerhan, C. The basin of Suceava river on Romanian territory. Valorise the tourist potential. Ph.D. Thesis, Bucharest University, Faculty of Geography, "Simion Mehedinți” Doctoral School, Bucharest, 421 pp., 2013. [in Romanian].

[34] McGarigal, K., Cushman, S.A. \& Ene, E. FRAGSTATS v4: Spatial pattern analysis program for categorical and continuous maps. Computer software program produced by the authors at the University of Massachusetts, 2012. http://www.umass.edu/landeco/research/fragstats/fragstats.html. [Accessed 12 January 2019].

[35] Cushman, S. A., McGarigal, K., \& Neel, M. C. Parsimony in landscape metrics: Strength, universality, and consistency. Ecological Indicators, 8 (5), pp. 691-703, 2008. DOI: 10.1016/j.ecolind.2007.12.002.

[36] Magurran, A. E. Ecological diversity and its measurement. Princeton, NJ: Princeton University Press, 192 pp., 1988.

[37] Cushman, S.A. \& McGarigal, K. Landscape Metrics, Scales of Resolution. In K. von Gadow and Pukkala T. (EDS.), Designing Green Landscapes, Springer B.V., pp. 33-51, 2008.

[38] Woodward, A. J. \& Fuhlendorf, S. D. Influence of landscape composition and change on lesser prairie-chicken (Tympanuchus pallidicinctus) populations The American Midland Naturalist, 145, pp. 261-274, 2001.

[39] Krajewski, P., Solecka, Iga \& Barbara-Mastalska-Cetera. Landscape Change Index as a Tool for Spatial Analysis. IOP Conference Series: Materials Science and Engineering. 245, 2017. DOI: 10.1088/1757-899X/245/7/072014.

*** Topographic Map of Romania, scale 1:25000, Second Edition, Military Topographic Department, Ministry of National Defense, 1986.

*** CORINE Land Cover data of 1990, 2000, 2006 and 2012 time steps https://land.copernicus.eu/pan-european/corine-land-cover. [Accessed 5 December 2018].

*** National Agency for Cadastre and Land Registration. INIS Viewer. Romania Ortophotomaps Year 2012. [Accessed 20 January 2019]. 